Огляди літератури, оригінальні дослідження, погляд на проблему, ювілеї

УДК 616-008.6-02:612.766.2-06:616.441-008.64]-092.9

DOI 10.11603/1811-2471.2019.v0.i1.10058

\title{
СТАН ЕНДОГЕННОї ІНТОКСИКАЦІЇ В ДИНАМІЦІ ІММОБІЛІЗАЦІЙНОГО СТРЕСУ НА ТЛІ ГІПОТИРЕОЗУ
}

\author{
○о. Є. Любович, І. М. Кліщ \\ ДВНЗ «Тернопільський державний медичний університет імені І. Я. Горбачевського МОз України»
}

РЕзЮмЕ. Стрес $є$ відображенням всіх адаптивних реакцій організму, неспецифічних біологічних феноменів, що виникають у відповідь на дію різних подразників і спрямовані на реалізацію пристосувальних механізмів, адаптують організм до стресового впливу. Важливе місце в реалізації адаптивно-пристосувальних реакцій організму посідають гормони щитоподібної залози, які здатні мобілізувати резерви організму для усунення пошкоджень, викликаних дією стресового чинника. Тиреоїдна вісь закономірно втягується в процеси адаптації організму до дії надзвичайних подразників. Однак самі зміни тиреоїдної функції при стресі й адаптації не дозволяють оцінити значення тиреоїдних гормонів у пристосувальних реакціях. Необхідно провести комплексне дослідження гормонального спектра та стану ендогенної інтоксикації в організмі експериментальних тварин зі зміненим тиреоїдним статусом в умовах додаткових стресових впливів різної природи.

Мета - вивчення показників ендогенної інтоксикації при іммобілізаційному стресі у щурів з експериментальним гіпотиреозом.

Матеріал і методи. Гіпотиреоз моделювали щоденним введенням рег os тиреостатика мерказолілу («Здоров'я», Україна) у дозі 25 мг/кг протягом 21-ї доби. Гострий іммобілізаційний стрес моделювали шляхом прив' язування піддослідних щурів у положенні на спині за 4 кінцівки без обмеження рухливості голови тривалістю 3 години. Для дослідження концентрації йодовмісних гормонів щитоподібної залози, показників ендогенної інтоксикації та активності катаболічних процесів використано спектрофотометричні та імуноферментні методи.

Результати. Встановлено, що за умов дефіциту йодовмісних гормонів щитоподібної залози показники ендотоксикозу суттєво вищі, ніж у тварин без змодельованої патології. При дослідженні впливу іммобілізаційного стресу на показники ендогенної інтоксикації встановлено, що на стадії тривоги розвитку стрес-реакції в еутиреоїдних тварин показники молекул середньої маси, еритроцитарний індекс інтоксикації та вміст циркулюючих імунних комплексів зростають, що вказує на посилення ендотоксикозу. На стадії резистентності відбувається певна стабілізація цих процесів. Однак при тривалому стресі (стадія виснаження) ступінь ендотоксикозу знову достовірно зростає, що свідчить про зниження резервних функцій організму.

У тварин із гіпотиреозом має місце поступове достовірне зростання ендотоксикозу на усіх стадіях розвитку стрес-реакції з максимумом на стадії виснаження.

Висновок. На тлі гіпотиреозу спостерігається більш інтенсивне, ніж в еутиреоїдних тварин, зростання ступеня ендотоксикозу на усіх стадіях розвитку стрес-реакції.

КлючОВІ СлОВА: стрес; гіпотиреоз; ендогенна інтоксикація.

Вступ. Зростання ендотоксикозу відбувається тоді, коли: інтенсивність надходження токсичних продуктів метаболізму різко збільшена, або ж коли пригнічується активність антитоксичної системи чи елімінація токсичних метаболітів [14]. При різних патологічних станах, коли кількість продуктів природних відходів організму у біологічних середовищах значно зростає, а також коли агресивні компоненти перевищують можливості їх біотрансформації, розвивається синдром ендогенної інтоксикації (CEI) [10].

Незважаючи на схожість патогенезу CEI, при різних патологічних станах він має певні специфічні ознаки $[9,10]$.

Гіпотиреоз посідає одне з провідних місць у структурі ендокринної патології [2]. Знижена продукція тиреоїдних гормонів впливає на функцію і стан багатьох органів та систем, зокрема імунної та антиоксидантної, що суттєво впливає на перебіг патологічних процесів за цих умов [11]. Дуже важливим аспектом дослідження даної патології стало вивчення особливостей ії прояву в умовах підвищених стресових впливів, зважаючи на те, що значна частина населення перебуває в умовах хронічного стресу. Тиреоїдна вісь закономірно втягується в процеси адаптації організму до дії надзвичайних подразників. Однак самі зміни тиреоїдної функції при стресі й адаптації, як і зміни медіаторної функції при тиреоїдній патології, не дозволяють оцінити значення тиреоїдних гормонів у пристосувальних реакціях. Необхідне комплексне дослідження гормонального спектра та стану ендогенної інтоксикації в організмі експериментальних тварин зі зміненим тиреоїдних статусом в умовах додаткових стресових впливів різної природи [10].

Мета дослідження - стан і динаміка показників ендогенної інтоксикації залежать від інтенсивності катаболічних процесів в ураженій тканині і швидкості елімінації утворених продуктів [8], тому ми поставили перед собою мету дослідити вплив зниженої продукції тиреоїдних гормонів на 
Огляди літератури, оригінальні дослідження, погляд на проблему, ювілеї

показники ендогенної інтоксикації при іммобілізаційному стресі у піддослідних тварин з експериментальним гіпотиреозом.

Матеріал і методи дослідження. Для вивчення особливостей перебігу стрес-реакції на тлі гіпотиреозу використовували білих щурів-самців лінії Вістар, яких утримували на стандартному раціоні віварію при вільному доступі до води відповідно до вимог «Правил проведення робіт з використанням експериментальних тварин» та Європейської конвенції із захисту хребетних тварин (Страсбург, 1986) [7, 15]. В кожну експериментальну групу методом випадкової вибірки було вклю-

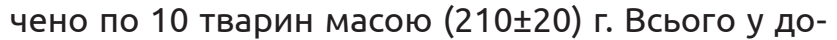
слідженні було використано 84 тварини, однак, внаслідок загибелі упродовж експерименту, на момент евтаназії було 80 тварин.

Гіпотиреоз моделювали щоденним введенням per os за допомогою зонда фармакопейного тиреостатика мерказолілу («Здоров'я», Україна) у дозі 25 мг/кг протягом 21-ї доби $[13,16]$. Повноту досягнення гіпотиреозу контролювали вимірюванням концентрації трийодтироніну і тироксину в сироватці крові, а також за динамікою маси тварин і їх рухової активності [13].

Вплив гіпотиреозу на перебіг імммобілізаційного стресу вивчали на моделі іммобілізаційного стресу [1]. Гострий іммобілізаційний стрес (ГІС) моделювали шляхом прив'язування піддослідних щурів у положенні на спині за 4 кінцівки без обмеження рухливості голови тривалістю 3 години. Дослідження проводили через 2 (стадія тривоги) та 48 (стадія резистентності) годин після завершення дії стресорного фактора. Хронічний іммобілізаційний стрес (ХІC), що є аналогом стадії виснаження, моделювали тим же методом, який повторювали протягом 5 діб. Дослідження проводили через 2 год після останнього моделювання.

Експериментальних тварин поділили на 8 груп:

- інтактні тварини, яким перорально вводили дистильовану воду протягом 21-ї доби;

- тварини, яким моделювали гіпотиреоз шляхом перорального уведення мерказолілу в дозі 25 мг/кг протягом 21-ї доби;

- тварини, яким моделювали гострий іммобілізаційний стрес і проводили евтаназію на стадії тривоги (2 год);

- тварини, яким моделювали гострий іммобілізаційний стрес і проводили евтаназію на стадії резистентності (48 год);

- тварини, яким моделювали гострий іммобілізаційний стрес на тлі попередньо змодельованого гіпотиреозу (стадія тривоги);

- тварини, яким моделювали гострий іммобілізаційний стрес на тлі попередньо змодельованого гіпотиреозу (стадія резистентності);
- тварини, яким моделювали хронічний іммобілізаційний стрес;

- тварини, яким моделювали хронічний іммобілізаційний стрес на тлі попередньо змодельованого гіпотиреозу.

Для дослідження використовували цільну кров та плазму крові. Тварин декапітували під тіопенталовим наркозом через 2 та 48 год від моменту завершення одноразової іммобілізації та через 2 год від моменту завершення моделювання хронічного іммобілізаційного стресу.

Вміст загального тироксину (Т4) і загального трийодтироніну (Т3) у сироватці визначали імунофлуоресцентним методом із використанням стандартних тест-наборів «Immulite 1000». Концентрацію гормонів виражали в пмоль/л.

Ступінь вираження ендотоксемії оцінювали за вмістом молекул середньої маси (МСМ) у сироватці крові, де MCM $_{1}$ - це вміст молекул середньої маси, визначений при довжині хвилі 254 нм, а $\mathrm{MCM}_{2}$ - при довжині хвилі 280 нм [3], а також вираженням пошкодження еритроцитарної мембрани, для чого розраховували еритроцитарний індекс інтоксикації (EII) [14]. Вміст циркулюючих імунних комплексів (ЦІК) у сироватці крові визначали преципітацією їх розчином поліетиленгліколю-6000 [4]. Активність катепсину D визначали за методикою, описаною у роботах $[5,12]$.

Результати й обговорення. 3 метою оцінки функціонального стану щитоподібної залози у тварин, яким моделювали гіпотиреоз, визначали концентрацію тиреоїдних гормонів у крові. Концентрація $\mathrm{T}_{3}$ у здорових щурів склала $(5,96 \pm 0,22)$ пмоль/л, а у тварин, яким вводили мерказоліл, показник був знижений у 2,7 раза і становив $(2,19 \pm 0,21)$ пмоль/л. Концентрація $\mathrm{T}_{4}$ в інтактних щурів склала $(10,16 \pm$ 0,69) пмоль/л, а після введення мерказолілу зменшилась у 2,4 раза від показника інтактних щурів і склала $(4,27 \pm 0,28)$ пмоль/л. Ми спостерігали також суб'єктивні ознаки гіпотиреозу - зменшення рухливості, інтенсивніше, ніж в інтактних тварин, зростання маси тіла, зміни шерсті. Це вказує на розвиток у тварин явищ гіпотиреозу внаслідок уведення мерказолілу в дозі 25 мг/кг протягом 21-ї доби.

Аналіз отриманих результатів експериментальних досліджень показав, що моделювання гіпотиреозу супроводжувалось зростанням ступеня ендотоксемії (табл. 1). Зокрема, вміст молекул середньої маси, що визначали при довжині хвилі $\lambda=254$ нм, склав 158 \% від рівня контрольних тварин, а при довжині хвилі $\lambda=280-129,5 \%$. На $21 \%$ зріс показник ElI. Зростав також вміст ЦІК 115 \% від рівня інтактних тварин. Це збігається з результатами інших дослідників, які також вказують на суттєве зниження катаболічних процесів за умов дефіциту тиреоїдних гормонів [11]. 
Огляди літератури, оригінальні дослідження, погляд на проблему, ювілеї

Таблиця 1. Динаміка показників ендогенної інтоксикації у щурів з іммобілізаційним стресом на тлі гіпотиреозу $(\mathrm{M} \pm \mathrm{m})$

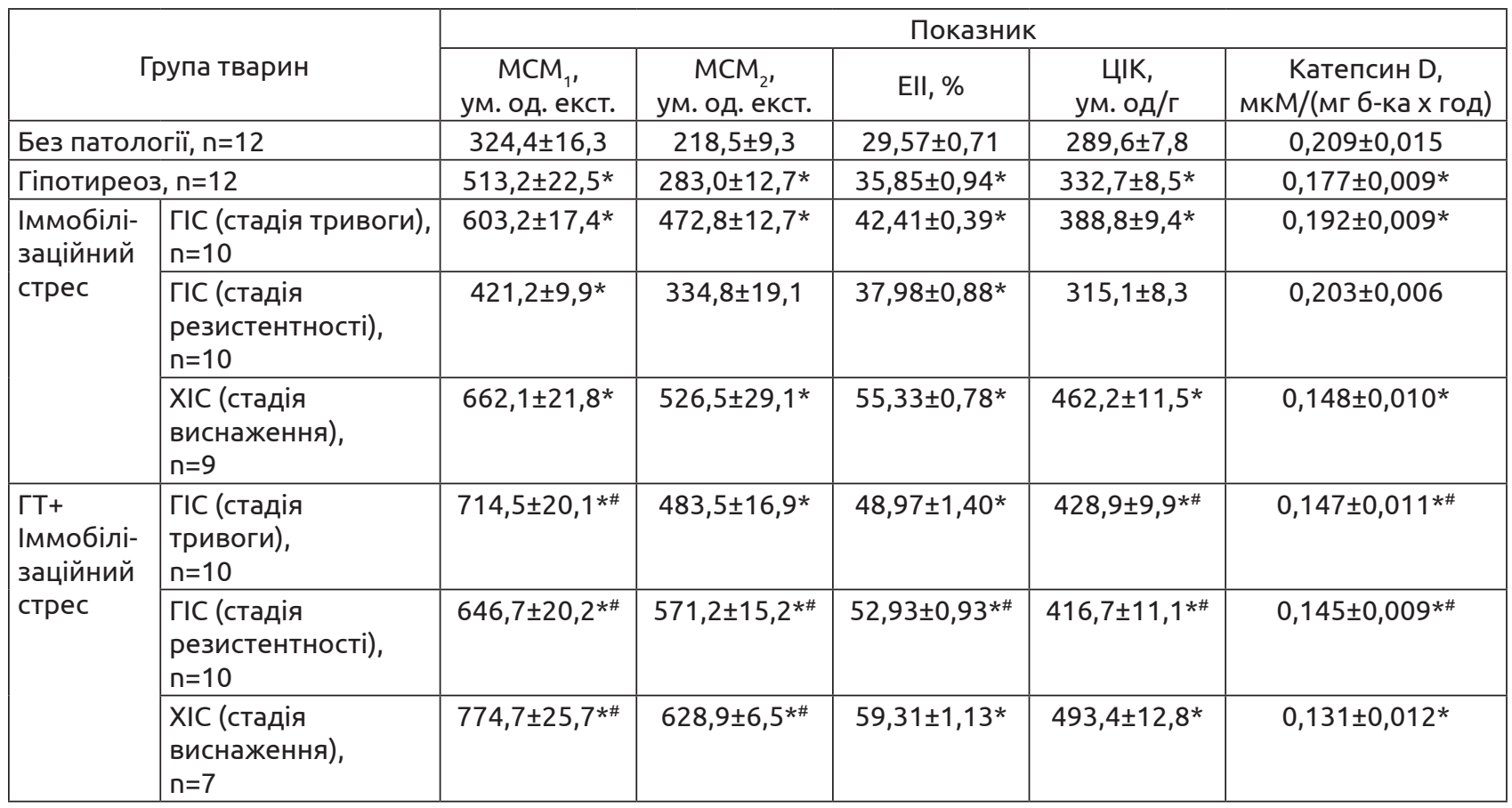

Примітка. * - зміни показників еутиреоїдних і гіпотиреоїдних тварин із гострим і хронічним стресом достовірні відносно інтактних $(p<0,05)$; \# - зміни показників гіпотиреоїдних тварин із гострим і хронічним стресом достовірні відносно показників еутиреоїдних на відповідні доби дослідження $(p<0,05)$.

Моделювання іммобілізаційного стресу супроводжувалось суттєвим зростанням ендотоксемії. Зокрема, вже на стадії тривоги вміст МСМ, був достовірно вищим від нормальних значень і склав $186 \%$ від рівня інтактних тварин. Показник MCM $_{2}$ зріс ще більше і склав $216 \%$ від норми, що вказує на інтенсивніше накопичення ароматичних сполук. Значне зростання зафіксовано і щодо еритроцитарного індексу інтоксикації - він склав 143,4 \% від рівня здорових тварин, що вказує на більшу чутливість цього показника у ранні терміни перитоніту. Рівень ЦІК у цей термін експерименту зріс на 34,3 \%, порівняно з контрольними тваринами. Однією із причин такого зростання може бути зниження активності катепсину D, внаслідок чого порушується процес деградації білкових комплексів.

На стадії резистентності ступінь ендогенної інтоксикації дещо зменшувався. Зокрема, вміст середньомолекулярних пептидів зріс, відповідно, на 30 та 53 \%, Ell - на $28 \%$. Рівень ЦІК не перевищував показника тварин без змодельованої патології. Водночас активність катепсину D також перебувала на рівні здорових тварин.

На стадії виснаження ми спостерігали подальше зростання показників, що характеризують ступінь ендогенної інтоксикації. Зокрема, вміст МСМ перевищував рівень інтактних тварин у 2 рази, $\mathrm{MCM}_{2}$ - у 2,4 раза. Значно вищими, порів- няно 3 попередніми термінами спостереження, були також EII (187,1 \%) та ЦІК (159,7 \%) від рівня інтактних тварин. Зменшилась також активність катепсину D - 70,8 \% від рівня тварин без змодельованої патології.

У тварин, яким іммобілізаційний стрес моделювали на тлі гіпотиреозу, ступінь ендотоксемії був значно вищим, ніж в еутиреоїдних тварин, яким моделювали цей патологічний стан. Зокрема, вже через 2 год від моменту моделювання ГІС показник MCM $_{1}$ зріс у 2,2 раза відносно інтактних тварин та був на 18,4 \% вищим від еутиреоїдних щурів із ГІС. Аналогічне зростання мало місце стосовно MCM $_{2}$ - відповідно, у 2,2 раза відносно інтактних та на $105 \%$ відносно еутиреоїдних щурів. Показник Ell склав 166 \% від норми, при цьому показник катепсину D склав 70 \% від норми. Рівень ЦІК склав 148 \% від норми і також перевищував показник еутиреоїдних тварин на $14 \%$. До 48-ї години від моменту моделювання ГІС показники, що характеризують стан ендогенної інтоксикації, дещо змінювались, порівняно з тими, які були зафіксовані у попередній термін спостереження. Зокрема, вміст МСМ склав $199 \%$, що менше, ніж на стадії тривоги, однак МСМ $_{2}$ склав $261 \%$, а це на 40 \% більше, ніж на стадії резистентності, достовірно перевищуючи також аналогічні показники еутиреоїдних тварин на цій же стадії процесу. Аналогічне зростання зафіксовано і щодо Ell 
Огляди літератури, оригінальні дослідження, погляд на проблему, ювілеї

179 \% від норми. Показник ЦІК практично не змінювався відносно попереднього терміну спостереження, перевищуючи, однак, аналогічний показник еутиреоїдних тварин на 36 \%. Показник катепсину D практично не змінився порівняно $з$ попереднім терміном спостереження, однак був достовірно меншим від аналогічного показника еутиреоїдних тварин.

На стадії виснаження у гіпотиреоїдних тварин показники ендотоксикозу продовжували зростати значно вищими темпами, ніж у групі тварин із нормальним вмістом тиреоїдних гормонів. Показник МСМ склав 239 \% від норми, перевищуючи аналогічний показник еутиреоїдних тварин на $34 \%$, а МCM $_{2}$ - відповідно, на $288 \%$, що на $47 \%$

\section{ЛІТЕРАТУРА}

1. Бондаренко С. Н. Влияние различных методик стрессирования и адаптации на поведенческие и соматические показатели у крыс / С. Н. Бондаренко, Н. А. Бондаренко, Е. Б. Манухина // Бюллетень экспериментальной биологии и медицины. - 1999. - Т. 128, № 8. - С. 157-160.

2. Епідеміологія захворювань щитоподібної залози в умовах йодної недостатності / А. О. Вацеба, В. М. Гаврилюк, В. І. Паньків [та ін.] // Лікар. справа. 2002. - № 1. - С. 31-33.

3. Габриэлян Н. И. Опыт использования показателя средних молекул в крови для диагностики нефрологических заболеваний у детей / Н. И. Габриэлян, В. И. Липатова // Лаб. дело. - 1984. - № 3. - С. 138-140.

4. Гриневич Ю. А. Определение иммунных комплексов в крови онкологических больных / Ю. А. Гриневич, А. М. Алферов // Лабораторное дело. -1981. - № 8. С. 493-495.

5. Дингл Дж. Методы исследования / Дингл Дж. М. : Мир, 1980. - 344 с.

6. Данилкина О. П. Физиология стресса животных [Електронний ресурс] / О. П. Данилкина ; Краснояр. гос. аграр. ун-т. - Красноярск, 2016. - 32 с.

7. Науково-практичні рекомендації з утримання лабораторних тварин та роботи з ними / [Кожем'якін Ю. М., Хромов О. С., Філоненко М. А. та ін.]. - К. : Авіцена, 2002. - 156 c.

8. Малахова М. Я. Методы биохимической регистрации эндогенной интоксикации / М. Я. Малахова // Эфферентная терапия. - 1995. - Т. 1, № 1. - С. 61-64.

9. Нетюхайло Л. Г. Молекули середньої маси - маркери ендогенної інтоксикації при експериментальній більше від тварин аналогічної групи без гіпотиреозу. На 201 \% зріс також Ell, а показник ЦІК склав 170 \% від норми, при цьому обидва показники достовірно перевищували рівень еутиреоїдних тварин з XIC. Все це відбувалось на тлі подальшого зниження активності катепсину $D$, який склав 63 \% від норми.

Висновок. Отже, дефіцит йодовмісних гормонів щитоподібної залози супроводжується достовірним зростанням показників, що характеризують синдром ендогенної інтоксикації, порівняно з еутиреоїдними тваринами. Це може бути однією із причин розвитку поліорганної недостатності за таких умов.

опіковій хворобі / Л. Г. Нетюхайло // Сучасні проблеми токсикології. - 2005. - № 3. - С. 43-46.

10. Остапенко В. А. К патогенезу синдрома эндогенной интоксикации / В. А. Остапенко // Эндогенные интоксикации. - СПб. : 1994. - С. 43.

11. Паньків В.І.Практична тиреоїдологія : монографія / В. І. Паньків. - Донецьк : Заславський О. Ю., 2011. -224 c.

12. Подунай Ю. А. Возрастная динамика активности катепсинов и содержания среднемолекулярных пептидов в мышцах морского ерша / Ю. А. Подунай, И. Н. Залевская, И. И. Руднева // Ученые записки Таврического национального университета им. В. И. Вернадского. - 2009. - Т. 22 (61). - № 4. - С. 128-134. - (Серия «Биология, химия").

13. Ром-Бугославська О. С. Доклінічне вивчення тиреостатичних та тиреоїд-стимулюючих засобів / О. С. Ром-Бугославська, Т. С. Божко, І. В. Комарова // Доклінічні дослідження лікарських засобів : метод. рекомендації. - К., 2001. - С. 409-420.

14. Тогайбаев А. А. Метод определения эндогенной интоксикации / А. А. Тогайбаев, А. В. Кургузкин, И. В. Рикун // Лаб. дело. - 1988. - № 9. - С. 22-24.

15. European convention for the protection of vertebrate animals used for experimental and other scientific purposes. - Council of Europe. Strasbourg. - 1986. № $123 .-52 \mathrm{p}$.

16. Isman C. A. Methimazole-induced hypothyroidism in rats ameliorates oxidative injury in experimental colitis / C. A. Isman, B. C. Yegen, I. Alican // J. Endocrinol. - 2003. Vol. 177, No. 3. - P. 471-476.

\section{REFERENCES}

1. Bondarenko, S.N., Bondarenko, N.A., \& Manukhina, E.B. (1999). Vliyaniye razlichnykh metodik stressirovaniya na povedencheskiye i somaticheskiye pokazateli u krys [Effect of various stressing techniques on behavioral and somatic indicators in rats]. Byuleten eksperimentalnoy biolo-

gii $i$ meditsiny - Bulletin of Experimental Biology and Medicine, 128 (8), 157-160 [in Russian].

2. Vatseva, A.O., Havryliuk, V.M., Pankov, V.I., Popovych, L.V., \& Neporadna, L.D. (2002). Epidemiolohiia zakhvoriuvan shchytopodibnoi zalozy $v$ umovakh yodnoi 
Огляди літератури, оригінальні дослідження, погляд на проблему, ювілеї

nedostatnosti [Epidemiology of diseases of the thyroid gland in conditions of iodine deficiency]. Likar. Sprava Medical Practice, (1), 31-33 [in Ukrainian].

3. Gabrielyan, N.I., \& Lipatova, V.I. (1984). Opyt ispolzovaniya pokazatelya srednikh molekul v krovi dlya diagnostiki nefrologicheskikh zabolevaniy u detey [Experience of using the average blood molecules for the diagnosis of nephrological diseases in children]. Lab. Delo - Laboratory Work, (3), 138-140 [in Russian].

4. Grinevich, Yu.A., \& Alferov, A.N. (1981). Opredeleniye immunnykh kompleksov v krovi onkologicheskikh bolnykh [Determination of immune complexes in the blood of cancer patients]. Lab. Delo - Laboratory Work, 8, 493-495 [in Russian].

5. Dingle, J. (1980) Metody issledovaniya [Research methods]. Moscow: Mir [in Russian].

6. Danilkina, O.P. (2015). Fiziologiya stressa [Physiology of stress]. Krasnoyarsk: Krasnoyarsk State Agrarian University [in Russian].

7. Kozhemiakin, Yu.M., Khromov, O.S., Filonenko, M.A., \& Sayfetdinova, H.A. (2002). Naukovo-praktychni rekomendatsii z utrymannia laboratornykh tvaryn ta roboty z nymy [Scientific and practical recommendations for the maintenance of laboratory animals and work with them]. Kyiv: Avitsenna [in Ukrainian].

8. Malakhova, M.Ya. (1995). Metody biokhimicheskoy registratsii endogennoy intoksikatsii [Methods of biochemical registration of endogenous intoxication] Efferentnaya terapiya - Efferent Therapy, 1 (1), 61-64 [in Russian].

9. Netiukhailo, L.H. (2005). Molekuly serednoi masymarkery endohennoi intoksykatsii pry eksperymentalnii opikovii khvorobi [Molecules of the middle mass as a marker of endogenous intoxication in experimental burns]. Sovremennye problemy toksikologii - Modern Problems of Toxicology, (3), 57-58 [in Ukrainian].
10. Ostapenko, V.A. (1994). K patogenezu sindroma endogennoy intoksikatsii [To the pathogenesis of the syndrome of endogenous intoxication]. Endogennyye intoksikatsii - Endogenous Intoxication. Saint-Petersburg [in Russian].

11. Pankov, V.I. (2011). Praktychna tyreoidolohiia [Practical thyroidology]. Donetsk: Publisher Zaslavskyi O. Yu. [in Ukrainian].

12. Podunay, Yu.A., Zalevskaya, I.N., \& Rudneva, I.I. (2009). Vozrastnaya dinamika aktivnosti katepsinov i soderzhaniya srednemolekulyarnykh peptidov v myshtsakh morskogo yersha [Age dynamics of cathepsin activity and the content of medium molecular peptides in the muscles of the sea ruff]. Uchenye zapiski Tavricheskogo Natsionalnogo universiteta im. V.I. Vernadskogo - Scientific Notes of V.I. Vernadsky Tauride National University, 22 (4), 128-134 [in Russian].

13. Rom-Bohuslavska, O.S., Bozhko, T.S., Komarova, I.V. (2001). Doklinichne vyvchennia tyreostatychnykh ta tyreoid-stymuliuiuchykh zasobiv [Preclinical study of thyroid statics and thyroid stimulants]. Doklinichni doslidzhennia likarskykh zasobiv: Metod. rekomendatsii - Pre-clinical studies of Medicines: Guidelines. (pp.409-420). Kyiv: Avitsenna [in Ukrainian].

14. Togaybayev, A.A., Kurguzkin, A.V., \& Rikun, I.V. (1988). Metod opredeleniya endogennoy intoksikatsii [Method for the determination of endogenous intoxication]. Lab. Delo - Laboratory Work, (9), 22-24 [in Russian].

15. Council of Europe (CoE) (1986). European Convention for the Protection of Vertebrate Animals used for experimental and other scientific purposes (ETS 123). CoE, Strasbourg.

16. Isman, C.A., Yegen, B.C., \& Alican, I. (2003). Methimazole-induced hypothyroidism in rats ameliorates oxidative injury in experimental colitis. Journal of Endocrinology, $177(3), 471-476$

\title{
СОСТОЯНИЕ ЭНДОГЕННОЙ ИНТОКСИКАЦИИ В ДИНАМИКЕ ИММОБИЛИЗАЦИОННОГО СТРЕССА НА ФОНЕ ГИПОТИРЕОЗА
}

\author{
๑О. Е. Любович, И. М. Клищ
}

\author{
Гвуз «Тернопольский государственный медицинский университет имени И. Я. Горбачевского \\ МОЗ Украчны»
}

РЕЗЮМЕ. Стресс является отражением всех адаптивных реакций организма, неспецифических биологических феноменов, возникающих в ответ на действие различных раздражителей и направленных на реализацию приспособительных механизмов, адаптирующих организм к стрессовому воздействию. Важное место в реализации адаптивно-приспособительных реакций организма занимают гормоны щитовидной железы, которые способны мобилизовать резервы организма для устранения повреждений, вызванных действием стрессового фактора. Тиреоидная ось закономерно вовлекается в процессы адаптации организма к действию чрезвычайных раздражителей. Однако сами изменения функции щитовидной железы при стрессе и адаптации не позволяют оценить значение тиреоидных гормонов в приспособительных реакциях. Необходимо провести комплексное исследование гормонального спектра и состояния эндогенной интоксикации в организме экспериментальных животных с измененным тиреоидными статусом в условиях дополнительных стрессовых воздействий различной природы.

Цель - изучение показателей эндогенной интоксикации при иммобилизационном стрессе у крыс с экспериментальным гипотиреозом.

Материал и методы. Гипотиреоз моделировали ежедневным введением рег оs тиреостатика мерказолила («Здоров'я», Украина) в дозе 25 мг/кг в течение 21-х суток. Острый иммобилизационный стресс моделировали путем привязывания подопытных крыс в положении на спине за 4 конечности без ограничения подвижности головы продолжительностью 3 часа. Для исследования концентрации йодсодержащих гормонов щитовидной же- 
Огляди літератури, оригінальні дослідження, погляд на проблему, ювілеї

лезы, вираженности эндогенной интоксикации использованы спектрофотометрические и иммуноферментные методы.

Результаты. Установлено, что в условиях дефицита йодсодержащих гормонов щитовидной железы показатели эндотоксикоза существенно выше, чем у животных без смоделированной патологии. При исследовании влияния иммобилизационного стресса на показатели эндогенной интоксикации установлено, что на стадии тревоги развития стресс-реакции у еутиреоидних животных показатели молекул средней массы, эритроцитарный индекс интоксикации и содержание циркулирующих иммунных комплексов растут, а это указывает на усиление эндотоксикоза. На стадии резистентности происходит определенная стабилизация этих процессов. Однако при длительном стрессе (стадия истощения) степень эндотоксикоза снова достоверно возрастает, что свидетельствует о снижении резервных функций организма.

У животных с гипотиреозом имеет место постепенный достоверный рост показателей эндотоксикоза на всех стадиях развития стресс-реакции с максимумом на стадии истощения.

Вывод. На фоне гипотиреоза наблюдается более интенсивный, чем у еутиреоидних животных, рост степени эндотоксикоза на всех стадиях развития стресс-реакции.

КЛЮЧЕВЫЕ СЛОВА: стресс; гипотиреоз; эндогенная интоксикация.

\section{THE STATE OF ENDOGENOUS INTOXICATION IN THE DYNAMICS OF IMMOBILIZATIONAL STRESS ON THE BACKGROUND OF HYPOTHYROIDISM}

\section{O. Ye. Liubovych, I. M. Klishch \\ I. Horbachevsky Ternopil State Medical University}

SUMMARY. Stress is a reflection of all adaptive reactions of the organism, nonspecific biological phenomena that arise in response to the action of various stimuli, aimed at the implementation of adaptive mechanisms, and adapt the body to stressful effects. An important role in the implementation of adaptive reactions of the body belongs to hormones of the thyroid gland, which can mobilize the body's reserves to eliminate the damage caused by the action of stress factor. The thyroid axis is naturally involved in the processes of adapting the organism to the action of extraordinary stimuli. However, the changes in the thyroid function themselves under stress and adaptation do not allow to assess the value of thyroid hormones in adaptive responses. A complex study of the hormonal spectrum and the state of endogenous intoxication in an organism of experimental animals with a changed thyroid status in conditions of additional stressful effects of different nature is necessary.

The aim - to study the indices of endogenous intoxication at immobilization stress in rats with experimental hypothyroidism.

Material and Methods. Hypothyroidism was modeled by daily introduction of Mercazolil thyrostatic per os ("Zdorovia", Ukraine) at a dose of $25 \mathrm{mg} / \mathrm{kg}$ during 21 days. Acute immobilization stress was modeled by binding the experimental rats in supine position by the 4 limbs without limiting the mobility of the head during 3 hours. Spectrophotometric and immuno-enzymatic methods were used to study the concentration of iodine-containing hormones of the thyroid gland, endogenous intoxication and activity of catabolic processes.

Results and Discussion. It was established that in conditions of deficiency of iodine-containing hormones of the thyroid gland, endotoxicosis rates are significantly higher than in animals without a simulated pathology. In the study of the effect of immobilization stress on indicators of endogenous intoxication, it was established that at the stage of anxiety of the development of stress reaction in euthyroid animals, the indices of the average mass molecules, the erythrocytic index of intoxication, and the content of circulating immune complexes increase, indicating an increase in endotoxicosis. At the stage of resistance there is a certain stabilization of these processes. However, with prolonged stress (the stage of exhaustion) the degree of endotoxicosis is increasing significantly, indicating a decrease in reserve functions of the body.

In animals with hypothyroidism, there is a gradual increase in endotoxicosis at all stages of the development of stress reaction with a maximum at the exhaustion stage.

Conclusions. In the setting of hypothyroidism, more intense than in euthyroid animals increase in the degree of endotoxicosis at all stages of the development of stress reaction was observed.

KEY WORDS: stress; hypothyroidism; endogenous intoxication. 